\title{
Community resilience elements and community risk perception at Banda Aceh province, Aceh, Indonesia
}

\author{
Ahmad Azan Ridzuan ${ }^{1, *}$, Rina Suryani Oktari ${ }^{2}$, Noor Azmi Mohd Zainol ${ }^{1}$, Haslinda Abdullah ${ }^{1}$, Jessica Ong Hai Liaw ${ }^{1}$, \\ Norlaila Mazura Hj. Mohaiyadin ${ }^{1}$, Khairunnisa Mardzuki ${ }^{1}$ \\ ${ }^{1}$ Faculty of Defence Studies and Management, National Defence University of Malaysia, 57000 Kuala Lumpur \\ ${ }^{2}$ Tsunami and Disaster Mitigation Research Centre Syiah Kuala University, 23233 Banda Aceh, Indonesia
}

\begin{abstract}
Issues related to the community resilience became more popular after the earthquake and Tsunami tragedy in the Indian Ocean and Aceh, Indonesia, 2004. The community resilience is the ability of communities to withstand and mitigate the stress of a disaster, there is less clearness on the detailed resilience-building process. The risk perception is concerns how an individual understands and experiences the phenomenon and believed to affect people's preparedness for, responses to and recovery from natural disasters. Aims of this study are to identify the relationship between the community resilience elements such as community experience, community exposure, community reaction, community attitude, community knowledge and the community risk perception using survey gathered from 542 samples of Banda Aceh Province community, Aceh, Indonesia. Results found out there is a significant relationship between the community resilience elements such as community experience, community exposure, community reaction, community attitude, community knowledge and the community risk perception. Statistically, results confirm that the implementation of the community resilience elements such as community experience, community exposure, community reaction, community attitude, and community knowledge act as an important determinant of community risk perception towards disasters risk management at Banda Aceh Province community.
\end{abstract}

\section{Introduction}

Disasters are a significant cause of death and disability around the world and also have great social, economic, and political effects on society [1]. Disasters can occur anywhere at any time, vary in severity, and have overwhelming magnitudes that may result in loss of life or injuries for the community who are ill-prepared for disaster situations.

Resilience to natural disasters as the ability of an actor to cope with or adapt to hazard stress [2]. Resilience was also defined as having three dimensions: The ability to absorb shocks; the ability to bounce back; and the ability to learn and adapt [3] [4]. The notion of resilience is an integral element at the international policy level to both the Hyogo Framework for Action and the Sendai Framework for Disaster Risk Reduction (United Nations Office for Disaster Risk Reduction, 2007 [5]; 2015 [6]) as well as to national and local discourses on disaster risk reduction or on the level of local authorities. Community resilience as continual learning and taking responsibility for making better decisions to improve the capacity to handle hazards [7].
A disaster resilient community is a community that can resist disaster and is able to take mitigation actions consistent with achieving the required level of protection [8].

Risk concerns both the probability for and the consequences of the happening of an event [9]. People are expected to vary in whether they focus upon probability or consequence [10]. Risk perception is defined as the subjective assessment of risk, not actual risk. Risk perception determines how people respond to hazards [11] [12]. The perceived risk concerns how an individual understands and experiences the phenomenon. Many factors may influence perceptions of risk, such as familiarity with the source of danger [13], control over the situation [14], and the dramatic character of the events - rare, striking events tend to be overestimated, while the frequency of common events tends to be underestimated. Risk perception, among other factors, is believed to affect people's preparedness for, responses to and recovery from natural disasters [15] [16].

Aims of this study are to identify the relationship between the community resilience elements such as community experience, community exposure,

\footnotetext{
Corresponding author: azan6142@yahoo.com
} 
community reaction, community attitude, community knowledge and the community risk perception.

\section{Literature review}

\subsection{Relationship between the community resilience elements and the community risk perception}

Extant studies about community resilience elements and community risk perception were conducted used a landline telephone to collect samples from respondents of 3,856 residents of coastal residents across five Gulf Coast States (Florida, Alabama, Mississippi, Louisiana, and Texas) [17]. Studied samples of 15,608 randomly selected addresses 3,272 surveys were returned from residents of the coastal regions South Carolina were surveyed on previous and potential perception of risk behaviors in regards to a hurricane strike to the conglomerates of Northern (Horry and Georgetown); Central (Charleston, Berkeley, and Dorchester) and Southern (Beaufort, Colleton, and Jasper) [18]. Another studied is to measure overall resilience in a community, focusing on risk perceptions citizens of Suita City, in the Osaka Prefecture of Japan [19]; and previous studied of samples from Cedar Rapids, Iowa a mail-out survey technique to 1000 households community resilience elements however 196 were completed and returned evacuees' perception of risk [20]. These studies found that the people's risk perception is believed be affected by community resilience (i.e., community experience, exposure, reaction, attitude, and knowledge) in respective disaster-affected areas [17] [18] [19] [20].

This finding is consistent with the notion of [21] illustrates that risk perception is made up of a variety of elements that vary by individual and community, including; socioeconomic factors, experience factors, trust of authorities, storm knowledge, home characteristics, and message dissemination. These variables interact with each other to either enhance or reduce risk perception. Dash and Gladwin's approach is to organize the factors involved in decision-making, understand how information is used, and determine what influences individual action. Another theory, according to [22] [23], cultural theory is a general sociological theory. Cultural theory aims at explaining how people perceive and act upon the world around them. More specifically the theory claims that this is largely determined by social aspects and cultural adherence. Both theories related to the literature that has been used to develop the conceptual framework for this study as shown in Figure 1.

\subsection{Conceptual framework and research hypothesis}

Figure 1 is the conceptual framework for this study. Researchers adopted the literature reviews as a fundamental to develop a conceptual framework for this study.

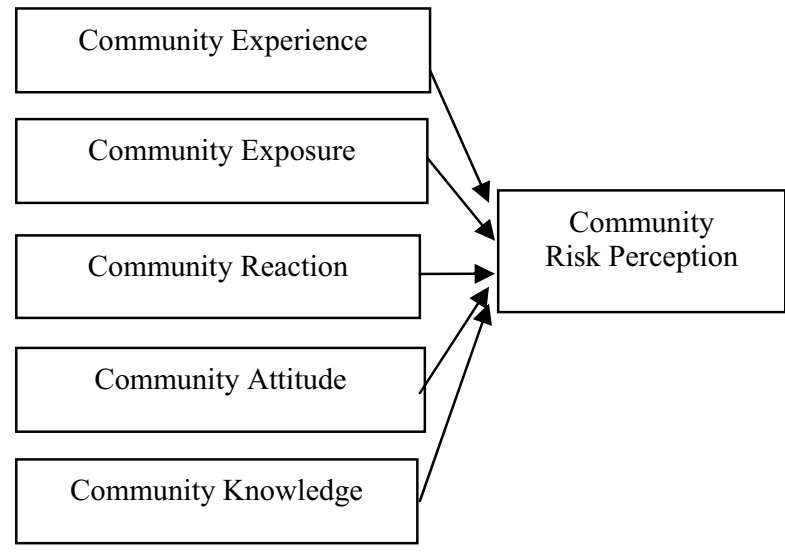

Fig. 1. The relationship between community resilience elements and the community risk perception.

Based on the framework, it can be hypothesized that:

H1: There is a significant relationship between the community experience and the community risk perception.

$\mathrm{H} 2$ : There is a significant relationship between the community exposure and the community risk perception.

H3: There is a significant relationship between the community reaction and the community risk perception. H4: There is a significant relationship between the community attitude and the community risk perception. H5: There is a significant relationship between the community knowledge and the community risk perception.

\section{Methodology}

\subsection{Research design}

A cross-sectional research design was employed because it allowed the researchers to combine the community resilience literature, the semi-structured interview and the actual survey as the main procedure to collect data for achieving the aims of this study. This research design is appropriate to help the researchers in collecting accurate, less bias and high-quality data [24] [25]. This study involved the local community who lives at Banda Aceh Province community, Aceh, Indonesia. At the initial stage of data collection, a survey was drafted based on the community resilience 
literature. As an exploratory phase for this study, the semi-structured interview was conducted involving six experienced local communities who lives more than 10 years comprising the head of local community, three from the in-charge of zone senior officer operations, a senior officer from Banda Aceh Province, and an officer-in-charge of government agency who had the relevant experience at Banda Aceh Province, Aceh, Indonesia. The feedback from this interview method was used to understand the nature and characteristics of the community resilience elements and the community risk perception. The pilot study was conducted to verify the content and format of the survey for an actual study. Due to the familiarity of the target respondents with the national language, i.e. Aceh, Indonesia, a backtranslation technique was employed to translate the content of survey from Malay into Aceh in order to enhance the validity and reliability of research findings $[24,25]$.

\subsection{Measures}

The survey had six sections whereby first to fifth section modified from related community resilience elements literature from [7,26,27]; six items for the Community Experience, six items for the Community Exposure, five items for the Community Reaction, six items for the Community Attitude, seven items for the Community Knowledge and five items for the Community Risk Perception. The survey was modified from related community risk perception characteristics [28,29]. All these items were measured using a seven scale ranging from "very strongly disagree" (1) to "very strongly agree" (7). Demographic variables were used as the controlling variables because this study focused on community resilience elements towards community risk perceptions.

\subsection{Unit of analysis and sample}

The researchers had obtained an official approval and received advice from the TDRMC Head to conduct the study at Banda Aceh Province community at Aceh, Indonesia. The targeted population for this study was the local community who lives at Banda Aceh Province community at Aceh, Indonesia. This head of local community allowed the researchers to conduct this study, but the list of the local community was not provided to the researchers. Considering this situation, a convenient sampling technique was used to distribute the survey to the local community who lives at Banda Aceh Province community at Aceh, Indonesia. A total of 600 surveys were distributed. From the total number, 542 usable surveys were returned to the researchers, yielding 90 percent response rate. The survey was answered by participants based on their consents and a voluntary basis. The number of the samples exceeds the minimum sample of 30 participants as required by probability sampling technique, showing that it may be analyzed using inferential statistics [25,30].

\subsection{Data analysis}

The research statistical analysis was conducted using a structural equation model generated by SmartPLS version 3.2.5 [26] [31]. The procedure of analyzing data is: first, validity test was performed by the convergent and discriminant validity. Second, the reliability analysis was performed by Cronbach alpha and composite reliability. Third, the structural model is assessed by examining the path coefficients using standardized betas $(\beta)$, t statistics and $p$ values. In addition, $\mathrm{R}^{2}$ is used as an indicator of the overall predictive strength of the model. The value of $\mathrm{R}^{2}$ are considered as follows; 0.19 (weak), 0.33 (moderate) and 0.67 (substantial) [32-33].

\section{Results}

\section{1 background of the respondent}

Most respondents are male (59\%), Aceh community $(90.2 \%)$, age group from 21 to 30 years old $(37.3 \%)$, non-married status community comprises (55.2\%), community lived more than 10 years (48\%), lived in the Jaya Baru, Banda Aceh (12.2\%), salary earned not available $(48 \%)$, an ordinary member of community social responsibility $(86.5 \%)$, and involved in community disaster preparedness activities - never (85.8) at Banda Aceh Province community in Aceh, Indonesia.

\subsection{Confirmatory factor analysis}

Table 1 shows the results of convergent and discriminant validity tests. All constructs had the values of AVE larger than 0.5 indicating that the met the acceptable standard of convergent validity [33] [34]. Besides that, all constructs had the values of $\sqrt{ }$ AVE in diagonal were greater than the squared correlation with other constructs in off-diagonal, showing that all constructs met the acceptable standard of discriminant validity [33].

Table 2 shows that all constructs loaded more strongly on their own constructs in the model, exceeding the specified minimum, 0.7 , showing that the validity of measurement model met the criteria [32] [34] [35]. Besides, the composite reliability and Cronbach's Alpha had values greater than 0.8 , indicating that the 
instrument used in this study maintained high internal consistency [33] [36].

Table 1. Fornell-Larcker criterion test

\begin{tabular}{|l|l|l|l|l|l|l|l|}
\hline $\begin{array}{l}\text { Con- } \\
\text { struct }\end{array}$ & AVE & (A) & (B) & (C) & (D) & (E) & (F) \\
\hline $\begin{array}{l}\text { Experi- } \\
\text { ence (A }\end{array}$ & 0.65 & 0.80 & & & & & \\
\hline $\begin{array}{l}\text { Expo- } \\
\text { sure (B) }\end{array}$ & 0.60 & 0.65 & 0.78 & & & & \\
\hline $\begin{array}{l}\text { Reaction } \\
\text { (C ) }\end{array}$ & 0.54 & 0.38 & 0.49 & 0.74 & & & \\
\hline $\begin{array}{l}\text { Attitude } \\
\text { (D) }\end{array}$ & 0.59 & 0.44 & 0.57 & 0.45 & 0.77 & & \\
\hline $\begin{array}{l}\text { Know- } \\
\text { ledge (E } \\
\text { ) }\end{array}$ & 0.60 & 0.37 & 0.48 & 0.39 & 0.59 & 0.78 & \\
\hline $\begin{array}{l}\text { Risk } \\
\text { Percep- } \\
\text { tion }\end{array}$ & 0.61 & 0.46 & 0.54 & 0.42 & 0.51 & 0.55 & 0.7 \\
\hline
\end{tabular}

Table 2. The results of factor loadings and cross loadings for different constructs and construct reliability analysis

\begin{tabular}{|l|c|l|c|c|}
\hline Construct & $\begin{array}{c}\text { Numbe } \\
\text { of } \\
\text { Items }\end{array}$ & $\begin{array}{l}\text { Cross } \\
\text { Factor } \\
\text { Loading }\end{array}$ & $\begin{array}{l}\text { Composit } \\
\text { Reliabilit }\end{array}$ & $\begin{array}{l}\text { Cron- } \\
\text { bach } \\
\text { Alpha }\end{array}$ \\
\hline $\begin{array}{l}\text { Communit } \\
\text { Experience }\end{array}$ & 6 & $\begin{array}{l}0.738- \\
0.854\end{array}$ & 0.916 & 0.890 \\
\hline $\begin{array}{l}\text { Communit } \\
\text { Exposure }\end{array}$ & 6 & $\begin{array}{l}0.729- \\
0.805\end{array}$ & 0.901 & 0.868 \\
\hline $\begin{array}{l}\text { Communit } \\
\text { Reaction }\end{array}$ & 5 & $\begin{array}{l}0.677- \\
0.780\end{array}$ & 0.855 & 0.792 \\
\hline $\begin{array}{l}\text { Communit } \\
\text { Attitude }\end{array}$ & 6 & $\begin{array}{l}0.708- \\
0.814\end{array}$ & 0.895 & 0.861 \\
\hline $\begin{array}{l}\text { Communit } \\
\text { Knowledg }\end{array}$ & 7 & $\begin{array}{l}0.740- \\
0.814\end{array}$ & 0.913 & 0.890 \\
\hline $\begin{array}{l}\text { Communit } \\
\text { Risk } \\
\text { Perception }\end{array}$ & 5 & $\begin{array}{l}0.722- \\
0.818\end{array}$ & 0.887 & 0.840 \\
\hline
\end{tabular}

\subsection{Outcomes of testing direct effects model}

Table 3 shows the outcomes of testing SmartPLS path model. The value of $\mathrm{R}^{2}$ is used as an indicator of the overall predictive strength of the model. The value of $\mathrm{R}^{2}$ is interpreted as follows: 0.19 , weak, 0.33 , moderate and 0.67, substantial [26] [32] [33] [37]. In this model testing, the inclusion of community experience, community exposure, community reaction, community attitude, and community knowledge in the analysis had explained 43.6 percent (moderate) of the variance in community risk perception.
The outcomes of direct effect model consisting of $\mathrm{H} 1, \mathrm{H} 2, \mathrm{H} 3, \mathrm{H} 4$, and H5. First, community experience significantly correlated with community risk perception $\left(\beta=0.131^{* *} ; \mathrm{t}=2.773\right)$, therefore $\mathrm{H} 1$ was supported. Second, the hypothesis of community exposure significantly correlated with community risk perception $\left(\beta=0.194^{* *} ; \mathrm{t}=3.243\right)$, therefore H2 was supported. Third, the hypothesis of community reaction significantly correlated with community risk perception ( $\left.\beta=0.100^{*} ; \mathrm{t}=2.072\right)$, therefore H3 was supported. Fourth, the hypothesis of community attitude significantly correlated with community risk perception ( $\left.\beta=0.120^{*} ; \mathrm{t}=2.466\right)$, therefore $\mathrm{H} 4$ was supported. Fifth, the hypothesis of community knowledge significantly correlated with community risk perception $\left(\beta=0.303^{* * *} ; \mathrm{t}=5.231\right)$, therefore H5 was supported.

Table 3. Estimation and prediction risk perception of $\mathrm{H} 1, \mathrm{H} 2$, $\mathrm{H} 3, \mathrm{H} 4$, and $\mathrm{H} 5$

\begin{tabular}{|c|c|c|c|c|}
\hline Relationships & $\beta$ & $\mathbf{t}$ & P value & $\mathbf{R}^{2}$ \\
\hline $\begin{array}{l}\text { H1: Community } \\
\text { Experience -----> } \\
\text { Community Risk } \\
\text { Perception }\end{array}$ & $0.131 * *$ & 2.773 & 0.006 & \multirow{5}{*}{0.430} \\
\hline $\begin{array}{l}\text { H2: Community } \\
\text { Exposure -------> } \\
\text { Community Risk } \\
\text { Perception }\end{array}$ & $0.194 * *$ & 3.243 & 0.001 & \\
\hline $\begin{array}{l}\text { H3: Community } \\
\text { Reaction -------> } \\
\text { Community Risk } \\
\text { Perception }\end{array}$ & $0.100 *$ & 2.072 & 0.039 & \\
\hline $\begin{array}{l}\text { H4: Community } \\
\text { Attitude --------- } \\
\text { Community Risk } \\
\text { Perception }\end{array}$ & $0.120 *$ & 2.466 & 0.014 & \\
\hline $\begin{array}{l}\text { H5: Community } \\
\text { Knowledge ----- } \\
\text { Community Risk } \\
\text { Perception }\end{array}$ & $0.303 * * *$ & 5.231 & 0.000 & \\
\hline
\end{tabular}

Note: Significant at $*_{\mathrm{t}}>1.96 ; * *_{\mathrm{t}}>2.576 ; * * * \mathrm{t}>3.29$

\section{Discussion and implications}

Findings of this study show that the community resilience elements such as community experience, community exposure, community reaction, community attitude, and community knowledge to act as an important determinant of community risk perception in the organizational sample. In the context of this study, the respective authority of Banda Aceh Province at Aceh, Indonesia has taken a proactive action to plan, maintain, and monitor its service to the community 
particularly expose to disaster. According to the interviewed respondents, community experience, community exposure, community reaction, community attitude, and community knowledge have been properly exposed to the community of Banda Aceh will contribute positively to community risk perception outcomes. Thus, the ability of the responsible authority of Banda Aceh to properly implement such emergency management plan has enhanced disaster risk perception in the studied areas.

This study provides significant impacts on three major aspects: theoretical contribution, the robustness of research methodology, and practical contribution. In terms of theoretical contribution, this study reveals that community resilience elements such as community experience, community exposure, community reaction, community attitude, and community knowledge act as important determinants of community risk perception. This finding also has supported and broadened studies by [17-20].

Regarding the robustness of research methodology, the survey used in this study have exceeded the minimum standards of validity and reliability analyses; this can lead to the production of accurate and reliable findings.

With respect to practical contribution, findings of this study can be used as a guideline by the responsible authority of Banda Aceh Province, Aceh, Indonesia to improve the risk perception of the community regarding the emergency management plan to get ready for future disaster. The possible suggestions are: firstly, the disaster training program needs to be properly provided to the responsible agencies and the community in order to increase their awareness and readiness for disaster response. Secondly, to consider better exposure to the individual in the community who are committed to improve disaster planning. Thirdly, selection of staff who served at respective responsible agencies of Banda Aceh Province at Aceh, Indonesia needs to have knowledge of disaster risk management so that they will be better efficiency in providing information to smoothly implement disaster response. If these suggestions are seriously considered this may motivate the community of Banda Aceh Province at Aceh, Indonesia to perform better emergency management plan in case the disaster occur in the future.

\section{Conclusion}

This study proposed the conceptual framework based on the community resilience and risk perception research literature. The measurement scales used in this study met the acceptable standards of validity and reliability analyses. The findings of the SmartPLS path model confirmed that the community resilience elements are important determinants of the community risk perception. This result has supported and broadened community resilience and risk perception research literature published in most Western countries. Therefore, current research and practice within risk perception models need to consider the community resilience as crucial elements of disaster risk management. Hence, these positive outcomes may lead to sustained and achieved the goals of the Banda Aceh Province at Aceh, Indonesia where its role and function are to provide safety, security, harmonious environment for the community to response for future disaster.

This research works was funded by research grant, NRGS/2013/UPNM/PK/P2, National Defense University of Malaysia and collaborated with Tsunami Disaster and Mitigation Research Centre, Universitas Syiah Kuala, Aceh, Indonesia

\section{References}

1. Perry, R.W., \& Lindell, M.K. (1997). Aged Citizens in the Warning Phase of Disasters: Re-Examining the Evidence. International Journal of Aging and Human Development, 44(4), 257-267.

2. Pelling, M. (2003). The vulnerability of Cities: Natural Disasters and Social Resilience. Earthscan Publications, London, UK. p. 48.

3. Ahmed, A. K. (2006). Concepts and practices of 'resilience': A compilation from various secondary sources. a working paper prepared for coastal community resilience (CCR) program, U.S. Indian Ocean Tsunami warning systems (IOTWS) program. Technical report, IRG-Tetra Tech Joint Venture.

4. Miller, F., Osbahr, H., Boyd, E., Thomalla, F., Bharwani, S., Ziervogel, G., Walker, B., Birkmann, J., van der Leeuw, S., \& Rockstr^om, J. (2010). Resilience and vulnerability: Complementary or conflicting concepts? Ecology and Society, 15(3).

5. United Nations Office for Disaster Risk Reduction. (2007). Hyogo Framework for Action 2005-2015: Building the Resilience of Nations and Communities to Disasters. United Nations International Strategy for Disaster Reduction.

6. United Nations Office for Disaster Risk Reduction. (2015). Sendai Framework for Disaster Risk Reduction 2015-2030. United Nations International Strategy for Disaster Reduction.

7. Cutter, S. L., Barnes, L., Berry, M., Burton, C., Evans, E., Tate, E., \& Webb, J. (2008). A placebased model for understanding community resilience to natural disasters. Global Environmental Change. 18: 598-606.

8. Cimellaro, G.P., Reinhorn, A.M., \& Bruneau, M. (2010). Framework for analytical quantification of 
disaster resilience. Engineering Structures, 32(11): p. 3639-3649.

9. Adams, J. (1995). Risk. London: UCL Press.

10. Drottz-Sjöberg, B.-M. (1991). Non-experts Definitions of Risk and Risk Perception (RHIZIKON: Risk Research Report No.3). Stockholm: Center for Risk research.

11. Pennings, J.M.E. \& Smidts, A. (2000). Assessing the Construct Validity of Risk Behavioral. Management Science, 46(10), 1337-1348.

12. Pennings, J.M.E. \& Smidts, A. (2003). The Shape of Utility Functions and Organizational Behavior. Management Science, 49(9), 1251-1263.

13. Ittelson, W.H. (1978). Environmental Perception and Urban Experience. Environment and Behaviour, 10, 193-213.

14. Rachman, S.J. (1990). Fear and Courage. San Francisco: WF Freeman.

15. Grothmann, T. \& Reusswig, F. (2006). People at Risk of Flooding: Why Some Residents Take Precautionary Action While Others Do Not. Natural Hazards. 38, 101-120.

16. Bradford, R. A., O'Sullivan, J. J., Van der Craats, I. M., Krywkow, J., Rotko, P., Aaltonen, J., Bonaiuto, M., DeDominicis, S., Waylen, K. and Schelfaut, K. (2012). Risk Perception-Issues for Flood Management in Europe. Natural Hazards and Earth System Sciences, 12, 2299-2309.

17. Goidel, K., Kenny, C., Climek, M., Means, M., Swann, L., Sempier, T., \& Schneider, M. (2012). Gulf Coast Climate Change Survey. ed. T. S. G. National Oceanic and Atmospheric Administration, Louisiana Sea Grant, Florida Sea Grant, MississippiAlabama Sea Grant Consortium.

18. Seigler, W.C. (2014). Analysis of Hurricane Preparedness Levels and Evacuation Intent for South Carolina Coastal Residents. Thesis Degree of Master of Earth and Environmental Resources Management in Earth and Environmental Resources Management College of Arts and Sciences University of South Carolina.

19. Maiko Ebisudanil \& Akihiro Tokai. (2016). Application of Risk Perception Theory to Develop a Measurement Framework for City Resilience: Case Study of Suita, Japan. Journal of Sustainable Development; Vol. 9, No. 5. 33-42.

20. Siebeneck, L.K., \& Cova, T.J. (2008). Risk Perception Associated with the Evacuation and Return-entry Process of the Cedar Rapids, Iowa Flood. A Quick Response Research Report for the Natural Hazards Center, Boulder, Colorado.

21. Dash, N., \& Gladwin, H. (2005). Evacuation Decision Making and Behavioral Responses: Individual and Household. Prepare for Hurricane Focus Social Economic Workshop, February, 16-18.
22. Douglas, M. (1978). Cultural Bias. Occasional Paper no. 35, Royal Anthropological Institute of Great Britain and Ireland.

23. Thompson, M., Ellis, R. \& Wildavsky, A. (1990). Cultural Theory. Boulder: Westview Press.

24. Creswell, J.W. (2012). Educational Research: Planning, Conduct, and Evaluating Quantitative and Qualitative Research (Fourth Edition). Boston: Pearson.

25. Sekaran, U., \& Bougie, R. (2011). Research Methods for Business: A Skill Building Approach. United Kingdom: John Wiley \& Sons, Ltd.

26. Paton, D. (2006). Disaster Resilience: Integrating individual, community, institutional and environmental perspectives. Disaster resilience: An integrated approach: p. 305-316.

27. Chang, S.E. \& Shinozuka, M. (2004). Measuring improvements in the disaster resilience of communities. Earthquake Spectra. 20(3): p. 739-755.

28. Howe, P.D. (2011). Hurricane preparedness as anticipatory adaptation: A case study of community businesses. Global Environmental Change. 21(2): p. $711-720$.

29. Gaillard, J.C. \& Texier, P. (2010). Religions, natural hazards, and disasters: An introduction. Religion. 40(2): p. $81-84$.

30. Chua, Y.P. (2006). Kaedah Penyelidikan. Kuala Lumpur: McGraw Hill.

31. Riggle, R. J., Edmondson, D. R., \& Hansen, J. D. (2009). A Meta-analysis of the Relationship between Perceived Organizational Support and Job Outcomes: 20 Years of Research. Journal of Business Research, 62: 1027-1030.

32. Chin, W.W. (1998). The Partial Least Squares Approach to Structural Equation Modelling, in Hoyle, R.H. Statistical Strategies for Small Sample Research, Sage Publication, Inc., Thousand Oaks California, 307-341.

33. Henseler, J., Ringle, C. M., \& Sinkovics, R. R. (2009). The Use of Partial Least Squares Path Modeling in International Marketing. In: Sinkovics, R. R., Ghauri, P. N. (Eds.), Advances in International Marketing. Bingley: Emerald, 277320.

34. Fornell, C. \& Larcker, D.F. (1981). Evaluating Structural Equation Models with Unobservable Variables and Measurement Error. Journal of Marketing Research, vol XVIII, no. February, 3950.

35. Gefen, D. \& Straub, D. (2005). A Practical Guide to Factorial Validity Using PLS-Graph: Tutorial and Annotated Example. Communication of the Association for Information Systems, 16, 91 - 109.

36. Nunally, J.C. \& Bernstein, I.H. (1994). Psychometric Theory. New York: McGraw-Hill. 
37. Wetzels, M., Odekerken-Schroder, G., \& van Oppen, C. (2009). Using PLS Path Modeling for Assessing Hierarchical Construct Models: Guidelines and Empirical Illustration. MIS Quarterly, 33 (1), 177-195. 